https://doi.org/10.17816/MAJ191S1215-217

\title{
TURMERIC EXTRACT IN CORRECTION OF NERVOUS AND IMMUNE SYSTEMS FUNCTIONAL ACTIVITY PARAMETERS IN EXPERIMENTAL ALCOHOLISM
}

\author{
E.V. Markova, ${ }^{1,2}$ I.A. Goldina ${ }^{1}$, B.G. Goldin ${ }^{2,3}$, M.A. Knyazheva ${ }^{1}$, I.V. Savkin ${ }^{1}$
}

${ }^{1}$ Laboratory of Neuroimmunology, Federal State Budgetary Scientific Research Institute of the Fundamental and Clinical Immunology, Novosibirsk, Russia;

${ }^{2}$ Novosibirsk State Pedagogical University, Novosibirsk, Russia;

${ }^{3}$ Federal State Budgetary Educational Institution of Higher Education "Novosibirsk State Medical University", Novosibirsk, Russia

\section{ЭКСТРАКТ КУРКУМЫ В КОРРЕКЦИИ ПОКАЗАТЕЛЕЙ ФУНКЦИОНАЛЬНОЙ АКТИВНОСТИ НЕРВНОЙ И ИММУННОЙ СИСТЕМ ПРИ ЭКСПЕРИМЕНТАЛЬНОМ АЛКОГОЛИЗМЕ}

\author{
Е.В. Маркова ${ }^{1,2}$, И.А. Гольдина ${ }^{1}$, Б.Г. Гольдин ${ }^{2,3}$, М.А. Княжева ${ }^{1}$, И.В. Савкин \\ ${ }^{1}$ ФГБНУ «НИИ фундаментальной и клинической иммунологии», Новосибирск; \\ ${ }^{2}$ ФГБОУ ВО «Новосибирский государственный педагогический университет», Новосибирск; \\ ${ }^{3}$ ФГБОУ ВО «Новосибирский государственный медицинский университет» Минздрава России, \\ Новосибирск
}

evgeniya_markova@mail.ru

The purpose of this work was to study the effect of turmeric extract on behavior indicators, the severity of the cellular immune response in animals in a state of experimental alcoholism.

Experimental models: mouse males (CBAxC57Bl/6)F1 three months of age $(n=60)$. Alcohol dependence in experimental animals was formed by the method of 6 -month soldering with a $10 \%$ ethanol solution. In the control groups, the animals received per os water or $10 \%$ ethanol solution, in the experimental group - an extract of turmeric powder in a solution of ethanol. Mice behavior was assessed in the "open field" test. The severity of the cellular immune response to sheep erythrocytes was assessed by the intensity of the development of a delayed-type hypersensitivity reaction.

It was found that the use of turmeric extract against the background of taking ethanol solution in animals with experimental alcoholism leads to the stimulation of behavior and the increase of the cellular immune response to the level characteristic of healthy animals of the corresponding age.

Results indicates the protective effect of turmeric on a number of parameters of the functional activity of the nervous and immune systems during chronic ethanol intoxication.

Keywords: experimental alcoholism; turmeric; behavior; cellular immune response.

Целью данной работы было изучение влияния экстракта куркумы на показатели поведения, выраженность клеточного иммунного ответа у животных в состоянии экспериментального алкоголизма.

Экспериментальная модель: мыши-самцы (CBAхC57Bl/6)F1 трехмесячного возраста $(n=60)$. Алкогольная зависимость у экспериментальных животных была сформирована методом 6-месячного спаивания $10 \%$ раствором этанола. В контрольных группах животные получали воду или $10 \%$ раствор этанола, в опытной группе - экстракт порошка куркумы в растворе этанола. Поведение мышей оценивали в тесте «открытое поле». Выраженность клеточного иммунного ответа к эритроцитам барана оценивали по интенсивности развития реакции гиперчувствительности замедленного типа.

Было установлено, что использование экстракта куркумы на фоне приема раствора этанола приводит у животных в состоянии экспериментального алкоголизма к стимуляции поведения и повышении клеточного иммунного ответа до уровня, свойственного здоровым животным соответствующего возраста.

Результаты свидетельствуют о протекторном эффекте куркумы в отношении ряда параметров функциональной активности нервной и иммунной систем при хронической интоксикации этанолом.

Ключевые слова: экспериментальный алкоголизм; куркума; поведение; клеточный иммунный ответ.

Introduction. Prolonged alcohol consumption affects the immune and nervous systems, causing a breakdown in their functional connections [1]. Considering the neuroprotective and immunotropic properties of rhizomes polyphenolic compounds of the plant Curcuma Longa L. (turmeric) [2-5], the purpose of this work was to study the effect of turmeric extract on behavior parameters and the severity of the cellular immune response in animals with experimental alcoholism.

Material and methods. The experiments were performed on male mice (CBAxC57BL/6)F1 
$(n=60)$, healthy and in a state of experimental alcoholism, formed by the method of 6-month soldering with a $10 \%$ ethanol solution. Turmeric powder (Supplier Test Report No. 561-374-1-16 / BM dated June 09, 2016) was dried ground turmeric (Mumbai, India). The solution of turmeric was a 15-day extract of dry powder in $40 \%$ ethanol $(150 \mathrm{~g} / \mathrm{l})$.

Control groups: healthy mice and alcoholic animals, received water or $10 \%$ ethanol solution, $5 \mathrm{ml}$ per animal per day. Animals of the experimental group took turmeric extract with a final ethanol concentration of $10 \%$, in the same volume, daily, for 2.5 months, then all animals were evaluated for behavior parameters in the "open field" test and the severity of the cellular immune response by the intensity of the development of a delayedtype hypersensitivity reaction (DTH), according to the methods described earlier $[6,7]$. Statistical processing of the results was performed using the Statistica 7.0 software package (StatSoft, USA) using the non-parametric Mann-Whitney test. Data are presented as $M \pm S D$. Differences were considered statistically significant at $p<0.05$.

Results and discussion. In experimental alcoholism, suppression of the motor and research components of animal behavior was recorded, as evidenced by a decrease in the parameters of motor activity: horizontal (peripheral from $88.4 \pm 16.2$ to $22.7 \pm 4.2, p<0.05$; central from $7.1 \pm 1.7$ to $0.1 \pm 0.1, p<0.05$ ) and vertical (free from $1.3 \pm 0.1$ to $0.3 \pm 0.1, p<0.05$; supported on the wall from $2.9 \pm 0.5$ to $1.1 \pm 0.2, p<0.05$ ) in comparison with the group of healthy animals of the corresponding age. In alcoholic mice treated with turmeric extract, behavioral stimulation was recorded compared to animals treated with ethanol solution (horizontal: peripheral from $22.7 \pm 4.2$ to $54.2 \pm 5.2, p<0.05$; central $0.1 \pm 0.1$ to $4.1 \pm 0.2$, $p<0.05$; vertical, wall-supported from $1.1 \pm 0.2$ to $2.3 \pm 0.1, p<0.05)$.

When assessing the severity of the DTH reaction after taking the extract of turmeric, the results presented in table 1 were obtained.

Consequently, the use of turmeric extract on the background of taking ethanol solution in alcoholic animals led to the stimulation of open field behavior and an increase in the cellular immune response to the level of healthy animals of appropriate age, which testifies to the protective effect of turmeric on a number of parameters of the functional activity of the nervous and immune systems during chronic ethanol intoxication.

Table 1

The severity of the delayed-type hypersensitivity reaction in alcoholic animals and after taking the extract of turmeric $(M \pm S D)$

\begin{tabular}{|c|c|c|c|}
\hline Groups of animals & Intact (control 1) & Ethanol (control 2) & Turmeric extract, ethanol \\
\hline DTH reaction index (\%) & $51.2 \pm 7.4$ & $23.3 \pm 5.1$ & $45.9 \pm 8.2^{*}$ \\
\hline
\end{tabular}

N o te. $n=20$ in each group, ${ }^{*} p<0.01$ compared with the control group 2.

\section{References}

1. Balanzá-Martínez V, Crespo-Facorro B, González-Pinto A, Vieta E. Bipolar disorder comorbid with alcohol use disorder: focus on neurocognitive correlates. Front Physiol. 2015;6:108.

2. Aggarwal BB, Yuan W, Li S, Gupta SC. Curcumin-free turmeric exhibits anti-inflammatory and anticancer activities: Identification of novel components of turmeric. Mol. Nutr. Food Res. 2013;57:1529-1542.

3. Goldina IA, Goldin BG, Gaidul KV. Clinical efficacy of turmeric in diseases of the nervous system. Neuroimmunology. 2015;XVII(2):265. (In Russ.)

4. Goldina IA, Gaidul KV. Biological activity and therapeutic properties of Curcuma Longa L. (Literature review). Vestnik NSU. 2015;13(1):141-149. (In Russ.)

5. Goldina IA, Markova EV, Goldin BG, et al. The protective properties of turmeric in ethanol-induced behavioral disorders. Saratov Journal of Medical Scientific Research. 2017;13(1):131-135. (In Russ.)

6. Markova E, Knyazheva M, Savkin I, Shushpanova T. Effect of original anticonvulsant meta-chloro-benzhydryl-urea on behavioral and immune parameters in mice with active and passive behavior types in experimental alcoholism. European Psychiatry. 2017;41(S):S742-S743. (In Russ.)

7. Markova EV, Obukhova LA, Kolosova NG. Parameters of cell immune response in Wistar and OXYS rats and their behavior in the open field test. Bulletin of Experimental Biology and Medicine. 2003;136(6):588-590. 